\title{
Effect of Wetting Agent on Nutrient and Water Retention and Runoff from Simulated Urban Lawns
}

\author{
Baoxin Chang, Benjamin Wherley, and Jacqueline Aitkenhead-Peterson \\ Department of Soil and Crop Sciences, Texas A\&M University, College \\ Station, TX 77843
}

\author{
Nadezda Ojeda \\ Department of Environmental Health and Engineering, Johns Hopkins \\ University, Baltimore, $M D$
}

Charles Fontanier

Department of Horticulture and Landscape Architecture, Oklahoma State University, Stillwater, OK 74078

\section{Philip Dwyer \\ Scotts Miracle-Gro Company, 14111 Scottslawn Road, Marysville, OH 43040}

Additional index words. N fertilization, nutrient movement, Stenotaphrum secundatum, turfgrass

\begin{abstract}
Wetting agents have been widely used in the turf industry for ameliorating hydrophobic soil conditions and improving water use efficiency. However, limited information is available regarding potential benefits of wetting agents on fine textured soil lawns where wettable soils are commonly found, because most prior studies have been conducted in sand-based turf systems. This 2 -year field study evaluated the potential for wetting agents to improve turf quality, as well as to reduce runoff losses of water and nutrients from st. augustinegrass [Stenotaphrum secundatum (Walt.) Kuntze] lawns. Over two seasons, turfgrass quality, percent green cover, and soil moisture in plots were evaluated in response to wetting agent and fertilizer treatments. During precipitation events, total runoff volumes were measured, as well as total export of nutrients including $\mathrm{NO}_{3}-\mathrm{N}, \mathrm{NH}_{4}-\mathrm{N}$, total dissolved $\mathrm{N}$, dissolved organic $\mathrm{N}$, dissolved organic $\mathrm{C}$, and $\mathrm{PO}_{4}-\mathrm{P}$. No runoff was detected from any treatments when precipitation was less than $13 \mathrm{~mm}$. St. augustinegrass turfgrass quality and soil moisture were slightly improved by wetting agent and fertilizer treatments during the study, but no significant effects of either of the treatments were found on runoff volumes or nutrient exports. Although turf was managed under deficit irrigation levels of $0.3 \times$ reference evapotranspiration, irrigation events were not withheld due to rainfall, and thus, little to no drought stress was observed during the study.
\end{abstract}

How to manage nutrients and irrigation have been major concerns for the turfgrass and ornamental industry in recent decades, especially within densely populated urban areas (Beard and Green, 1994; Carey et al., 2012; Hochmuth et al., 2012). It is estimated that $40 \%$ to $60 \%$ of residential water use in

\footnotetext{
Received for publication 5 Mar. 2020. Accepted for publication $10 \mathrm{Apr} .2020$.

Published online 21 May 2020.

We wish to acknowledge the support of ScottsMiracle Gro Company and the Texas Turfgrass Research, Extension and Education Endowment for support of this research. This study was conducted under Hatch Tex0-1-9194 (Aitkenhead-Peterson) and Tex0-1-9518 (Wherley).

B.C. is the corresponding author. E-mail: changbaoxin@ tamu.edu.

This is an open access article distributed under the CC BY-NC-ND license (https://creativecommons. org/licenses/by-nc-nd/4.0/).
}

the United States is applied for irrigating landscapes, which are typically composed primarily of turfgrass (White et al., 2004). In Texas, lawn and landscape use of municipal water is significant (Cabrera et al., 2013). Due to the magnitude of use, water conservation and mitigation strategies have been used in the United States to reduce domestic water usage (Ozan and Alsharif, 2013). The environmental fate of nutrients has also become the focus of government policies restricting fertilizer use (Hochmuth et al., 2012). Several potential environmental concerns have also been attributed to turfgrass management, including offsite movement of water, nutrients, and pesticides in surface and groundwater and excessive use of potable water (Carey et al., 2012; King et al., 2001; King and Balogh, 2001; Racke, 2000). Management practices and/or application of products that enhance water and nutrient use efficiency could therefore aid in producing a more sustainable turfgrass system while reducing environmental impacts (Carrow et al., 2001).

Soil water repellency, or hydrophobicity, is a widespread problem for turfgrass managers, and it is usually associated with sandbased turfgrass systems (Zontek and Kostka, 2012). Hydrophobicity develops due to formation of hydrophobic organic substances around soil particles associated with living or decomposing plants or microorganisms (Doerr et al., 2000; Zisman, 1964). Although all types of soil can become hydrophobic, sandy soils tend to be more susceptible to water repellency due to their lower surface area per unit volume than finer-textured soils (DeBano et al., 1970; Karnok et al., 2004).

Soil water repellency not only reduces water use efficiency but may also increase runoff volumes during rainfall or irrigation events (Doerr et al., 2003; Mitra et al., 2006). Water lost as surface runoff has the potential to transport nutrients including nitrogen, potassium, and phosphorus (Burwell et al., 1975; Göbel et al., 2007; McDowell and Sharpley, 2001). Urban storm water runoff has been considered by the U.S. Environmental Protection Agency (EPA) to be a major factor influencing surface water (rivers, streams, and lakes) quality (Hoss et al., 2016; Novotny and Olem, 1994). Nitrogen and phosphorus losses in urban runoff have received considerable attention due to their impacts on surface water quality, including contributions to eutrophication (Taylor et al., 2005; Wherley et al., 2017).

Wetting agents reduce the surface tension of water, and thus have been widely used to reduce soil water repellency (Laha et al., 2009). Wetting agent molecules commonly consist of a lipophilic/nonpolar head and polar/hydrophilic tail; which, when applied to water-repellent soil, the polar side of wetting agent molecules was bonded to water molecules and the nonpolar side was bonded to water-repellent soil, respectively, wetting soil particles (Karnok et al., 2004). Repeated applications of wetting agents are often necessary to alleviate soil water repellency. A number of wetting agents are available on the market, and Zontek and Kostka (2012) have proposed a classification system for these products based on mode of action and/or interaction with water and soil, which include anionic and anionic blends, nonionic, cationic, or amphoteric wetting agent groups.

Most commercially available wetting agents claim an ability to reduce soil hydrophobicity and/or enhance water infiltration (Karnok et al., 2004; Pelishek et al., 1962). An evaluation of ten wetting agents was conducted over nine predominantly sandbased study sites across the United States, with the authors reporting efficacy for several of the selected wetting agents at reducing water drop penetration time (WDPT) across multiple study sites (Throssell, 2005). Kostka and Bially (2005) tested the synergetic effects of different wetting agent chemistries for the enhancement of hydrophilicity columns filled with water-repellent sand and 
reported that blends of unrelated nonionic wetting agents markedly improved infiltration over other commercial penetrant products. Most of these prior wetting agent studies have been conducted on sand-based systems, as putting greens are prone to local dry spots resulting from poor moisture retention, and limited studies have conducted on loam or clay soils typical of many lawns (Aamlid et al., 2009; Cisar et al., 2000; Leinauer et al., 2001; Soldat et al., 2010).

Given the benefits of wetting agents at improving water infiltration and consequent nutrient availability in the root zone of plants growing in coarse textured soils, there is growing commercial interest in evaluating wetting agents for use in home lawns. Application of these products may also be beneficial for lawns established on nonhydrophobic but poorly drained native soils given their reported potential to improve water infiltration and water content uniformity at greater soil depths (Lehrsch et al., 2011; Lowery et al., 2002; National Cooperative Soil Survey).

With a hypothesis that applying a wetting agent can improve turf quality and allocate more water and nutrient in the soil, the objectives of this research were to 1) evaluate the potential of wetting agents to improve turf performance and 2) test the effect of wetting agents on water and nutrient conservation, in terms of soil moisture content and the losses of water and nutrients in runoff from st. augustinegrass [Stenotaphrum secundatum (Walt.) Kuntze] lawns.

\section{Materials and Methods}

This study was conducted at the Urban Landscape Runoff Facility located at the Texas A\&M University Soil and Crop Sciences Field Research Laboratory, College Station, TX. The first study period was from 15 June 2015 to 26 Oct. 2015, and the second study period was from 21 July 2016 to 6 Dec. 2016 (each year comprised 21 weeks). The facility consisted of 24 individually irrigated plots (each $4.1 \mathrm{~m} \times 8.2 \mathrm{~m}$ ) with 3-4-year-old 'Raleigh' st. augustinegrass established on a $3.7 \%+/-0.5 \%$ slope atop a relatively undisturbed Boonville fine sandy loam soil (fine, smectitic, thermic, Chromic Vertic Albaqualf). Four soil samples were randomly taken at the depth of $10 \mathrm{~cm}$ on each plot using a 2-cm wide soil sampler probe (TSS2-S; Turf-Tec International) before the initiation of the study, and samples were sent to Texas A\&M University soil testing laboratory for nutrient analyses. All soil samples were oven dried at $65{ }^{\circ} \mathrm{C}$ for at least $16 \mathrm{~h}$. Following oven drying, samples were pulverized using a soil grinder (Agvise Laboratories, Benson, $\mathrm{MN}$ ), and all particles that could not pass a 2$\mathrm{mm}$ soil sieve were removed. An extracted soil solution with a ratio of 1:2 (soil: deionized water) was used to determine soil $\mathrm{pH}$ using a $\mathrm{pH}$ meter (Model 215; Denver Instrument, Bohemia, NY). We extracted P, K, $\mathrm{Ca}, \mathrm{Mg}, \mathrm{Na}$, and $\mathrm{S}$ using the Mehlich III extractant (a dilute acid-fluoride-EDTA solution of $\mathrm{pH} 2.5$ that consists of $0.2 \mathrm{~N} \mathrm{CH}_{3}$ $\mathrm{COOH}, 0.25 \mathrm{~N} \mathrm{NH}_{4} \mathrm{NO}_{3}, 0.015 \mathrm{~N} \mathrm{NH}_{4} \mathrm{~F}$, $0.013 \mathrm{~N} \mathrm{HNO}_{3}$, and $0.001 \mathrm{M}$ EDTA), and these were determined by inductively coupled plasma spectroscopy. Organic C was determined by a combustion procedure. A soil testing report showed average of 1.95 $\mathrm{g} \cdot \mathrm{kg}^{-1}$ organic $\mathrm{C}, \mathrm{pH} 6.9$, and adequate levels of soil P $\left(190 \mathrm{~g} \cdot \mathrm{kg}^{-1}\right), \mathrm{K}\left(217 \mathrm{~g} \cdot \mathrm{kg}^{-1}\right), \mathrm{Ca}$ (1243 g. $\left.\mathrm{kg}^{-1}\right)$, and $\mathrm{Mg}\left(117 \mathrm{~g} \cdot \mathrm{kg}^{-1}\right)$ [for reference, the critical levels provided by the soil testing report are $\mathrm{P}\left(50 \mathrm{~g} \cdot \mathrm{kg}^{-1}\right), \mathrm{K}\left(175 \mathrm{~g} \cdot \mathrm{kg}^{-1}\right)$, $\left.\mathrm{Ca}\left(180 \mathrm{~g} \cdot \mathrm{kg}^{-1}\right), \mathrm{Mg}\left(50 \mathrm{~g} \cdot \mathrm{kg}^{-1}\right)\right]$, which likely resulted from prior use of the area as a dairy research farm.

Before the initiation of the study, water droplet penetration time (WDPT) testing was conducted at the 2.5 - and 5-cm soil depths for plots that were assigned for all treatments, according to the method of Bisdom et al. (1993). Four 15-cm soil cores were randomly collected from each plot using a soil sampler probe (TSS2-S; Turf-Tec International). In the field, one water drop was placed on the exposed soil core at $2.5-$ and $5-\mathrm{cm}$ soil depths. The time that the water drop fully penetrated the soil core was recorded and averaged for each plot.

Each plot was equipped with a flow meter (ISCO 4210; Teledyne Isco, Lincoln, NE) and auto-sampler (ISCO 6712; Teledyne Isco), installed at the end of a flume that was attached to a runoff collection trough at the base of each plot. This setup allowed for measurement of runoff flow rate as well as the collection of runoff samples during runoff events, whether occurring due to precipitation or irrigation. A detailed description of the facility was published (Wherley et al., 2014).

Temperature data (average ${ }^{\circ} \mathrm{C}$ ) were obtained from Weather Underground archives for station KCLL in 2015 and an on-site weather station in 2016. Rainfall volumes $(\mathrm{mm})$ were measured on site using a tipping rain gauge (Isco 647; Teledyne Isco) at a 2minute temporal resolution.

In an effort to produce moderate soil moisture stress in plots, turfgrasses were irrigated once weekly at a rate of $30 \%$ of historical (30-year) reference evapotranspiration $\left(30 \% \times \mathrm{ET}_{\mathrm{o}}\right)$ for the City of College Station, based on data from the Texas ET network (Texaset.tamu.edu). For reference, the consumptive water requirement for most warm-season turfgrasses including st. augustinegrass is $\approx 0.6 \times \mathrm{ET}_{\text {o }}$ (Wherley et al., 2015). Analysis of applied irrigation water was as follows: $\mathrm{pH}$ (8.4), Bicarbonate (509 $\left.\mathrm{mg} \cdot \mathrm{L}^{-1}\right)$, Na $\left(234 \mathrm{mg} \cdot \mathrm{L}^{-1}\right), \mathrm{Cl}\left(81 \mathrm{mg} \cdot \mathrm{L}^{-1}\right)$, and sodium adsorption ratio (33.7). The irrigation volumes alone were not enough to induce runoff from plots, and so data presented are the result of runoff derived from precipitation. Rainfall was not accounted for during irrigation application; thus the experiment mimicked a "set-it and-forget-it" practice common among urban lawn landscapes in the region. Plots were mowed up to two times weekly at a $7.6 \mathrm{~cm}$ height of cut during the study period, with clippings returned to their respective plots. Oxadiazon (Ronstar G; Bayer, Research Triangle Park, NC) was applied to all plots at $4 \mathrm{~kg} \cdot \mathrm{ha}^{-1}$ a.i. in March of each season to prevent annual weed encroachment. For fall disease prevention, pyraclostrobin + triticonazole (Pillar G Intrinsic Brand Fungicide; BASF, Research Triangle Park, NC) was applied to all plots during October and November at a rate of $14.7 \mathrm{~g} \cdot \mathrm{m}^{-2}$.

The study was arranged as a randomized complete block design with four replicate plots per treatment. Treatments were arranged as a $2 \times 2$ factorial design with a wetting agent (WA) and fertilizer (Fert) as the main factors. A WA (Everydrop; Scotts Miracle-Gro, Marysville, $\mathrm{OH}$ ) was applied four times annually at either 0 or $0.9 \mathrm{~g} \cdot \mathrm{m}^{-2}$ a.i. per application, and urea and ammoniacalbased Fert $(32 \mathrm{~N}-0 \mathrm{P}-8.3 \mathrm{~K})$ was applied twice annually at 0 or $4.5 \mathrm{~g} \cdot \mathrm{m}^{-2} \mathrm{~N}$ per application (Table 1). Thus, four treatments were included in this study: 1) Both Fert and WA applied; 2) Only Fert applied; 3) Only WA applied; and 4) Control. Fertilizer and wetting agent treatments were applied using a drop spreader (Turf Builder 76565; Scotts Miracle-Gro, Marysville, $\mathrm{OH}$ ) and incorporated with $0.3-\mathrm{cm}$ irrigation.

Measurements for turfgrass quality, turfgrass coverage, and soil volumetric water content were recorded on the day before irrigation and again $2 \mathrm{~d}$ post irrigation. Turfgrass quality was visually evaluated using a 1-9 scale, with 1 representing the poorest or completely dead grass, 9 representing outstanding turf with perfect green color and density, and 6 being minimally

Table 1. Application date of fertilizer and wetting agent for 2015 and 2016.

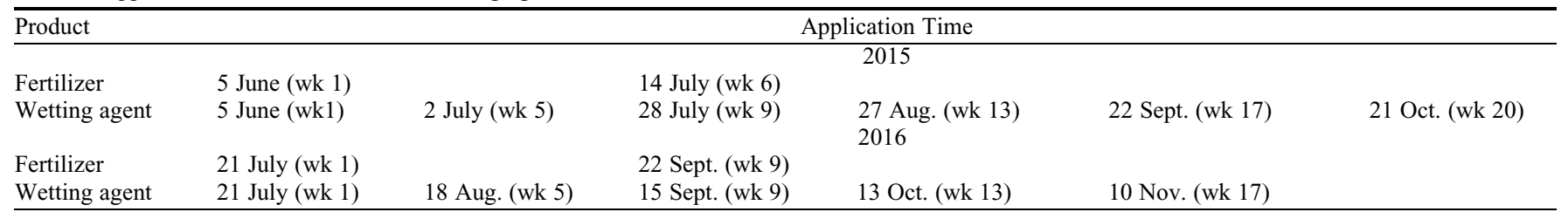




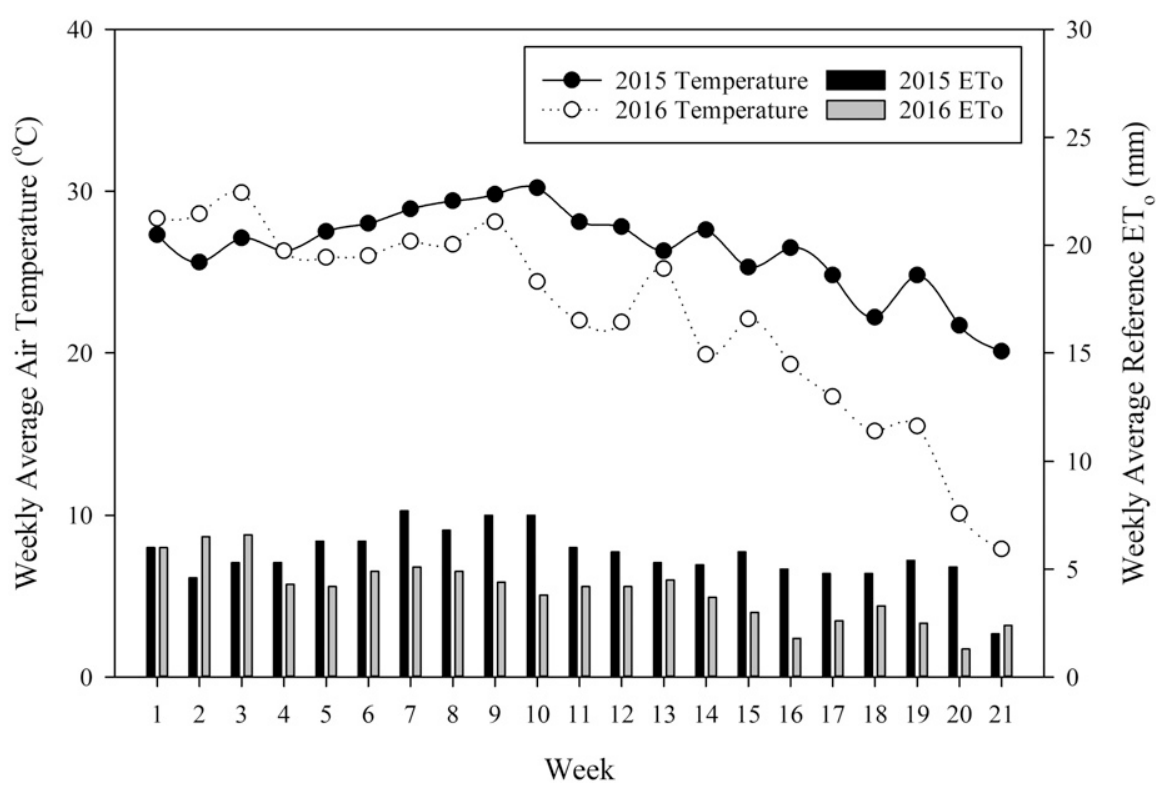

Fig. 1. Weekly average air temperatures $\left({ }^{\circ} \mathrm{C}\right)$ and reference evapotranspiration $\left(\mathrm{ET}_{\mathrm{o}}, \mathrm{mm}\right)$ during the study periods for 2 years. The 2015 study was conducted from 5 June to 26 Oct., while the 2016 study was conducted from 21 July to 6 Dec. Data were obtained from an onsite weather station.

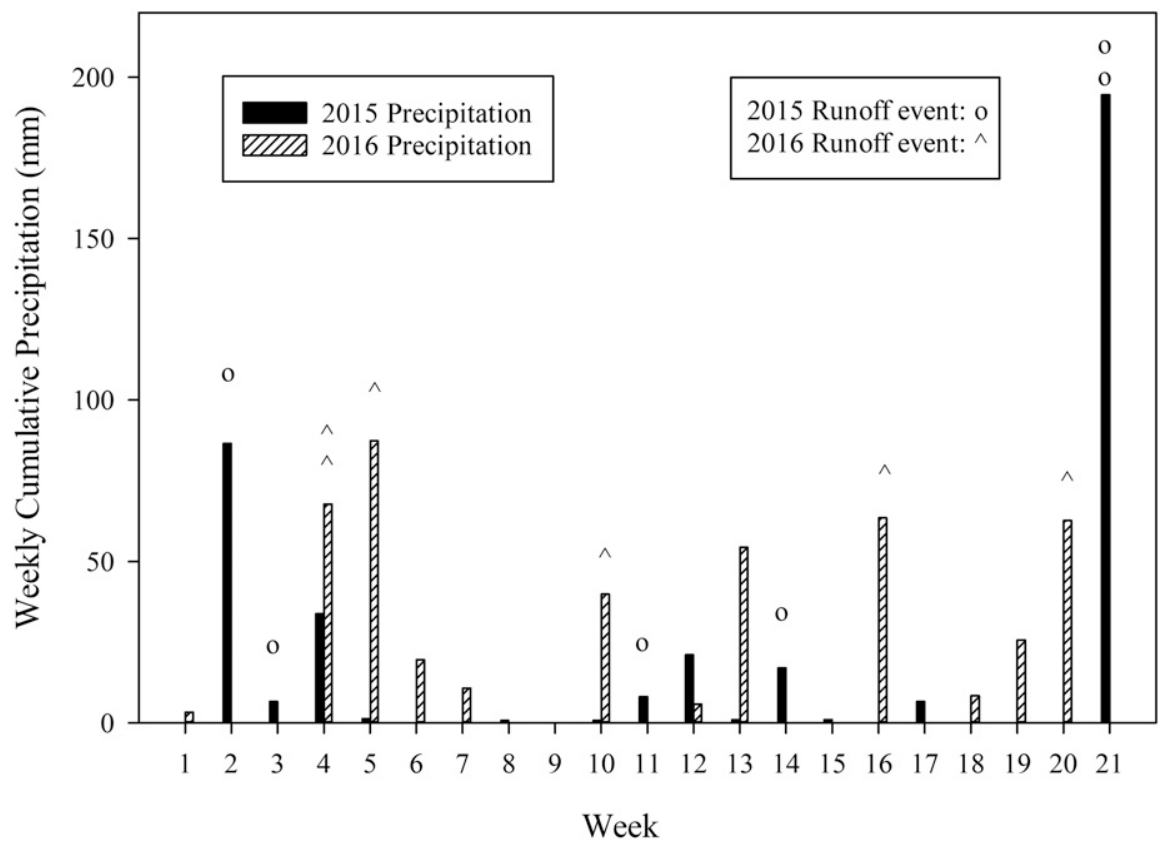

Fig. 2. Weekly cumulative precipitation $(\mathrm{mm})$ and all runoff events detected in 2015 and 2016. The 2015 study was conducted from 5 June 2015 to 26 Oct. 2015 , while the 2016 study was conducted from 21 July 2016 to 6 Dec. 2016. For 2015: $\mathrm{O}=1$ runoff event and $2 \times \mathrm{O}=2$ runoff events for that week. For 2016: ${ }^{\wedge}=1$ runoff event and $2 \times^{\wedge}=2$ runoff events for that week.

acceptable quality (Morris and Shearman, 2007). In addition, light box images were taken twice weekly on Tuesdays and Fridays for evaluation of percent green cover in a randomly selected location within each plot using a Nikon Coolpix 7100 digital camera (Nikon Co., Minato, Tokyo, Japan) mounted on a $0.6-\times 0.6-\mathrm{m}$ square light box equipped with four compact fluorescent bulbs. Images were analyzed for percentage green cover using SigmaScan version 5.0 (Systat Software Inc., San Jose, CA) and a batch analysis
TDR 300; Spectrum Technologies Inc., Aurora, IL), and the plot soil volumetric water content was the average of four measurements.

Flow meter triggered collection of a runoff sample after every $0.13 \mathrm{~cm}(37.8 \mathrm{~L})$ of runoff. Total runoff volume (L) of each event was determined. Aliquots of the runoff samples from each plot were vacuum filtered through $0.7-\mu \mathrm{m}$ nominal pore size glass microfiber filters (Ahlstrom, Munksjo Filtration LLC, Madisonville, KY) to provide sediment removal and rapid flow rate. Electrical conductivity (EC) of unfiltered runoff samples were measured for each runoff event with a portable EC meter (C65; Milwaukee Instruments Inc., Rocky Mount, NC). Filtered runoff samples were used to measure concentrations of $\mathrm{NO}_{3}-\mathrm{N}, \mathrm{NH}_{4}-\mathrm{N}$, and $\mathrm{PO}_{4}-\mathrm{P}$ by using a discrete wet chemistry analyzer (SMARTCHEM 200; Unity Scientific, Brookfield, CT). Colorimetric with automated $\mathrm{Cd}-\mathrm{Cu}$ reduction (Method: EPA 353.2), colorimetric automated phenate (Method: EPA 350.1), and colorimetric automated ascorbic (Method: EPA 365.1) were used to measure $\mathrm{NO}_{3}-\mathrm{N}, \mathrm{NH}_{4}-\mathrm{N}$, and $\mathrm{PO}_{4}-\mathrm{P}$, respectively. Concentrations of total dissolved nitrogen (TDN) and nonpurgeable dissolved organic carbon (DOC) were measured using high-temperature Pt-catalyzed combustion with a Shimadzu TOC-VCSH and Shimadzu total measuring unit TNM-1 (Shimadzu Corp., Houston, TX). Because a direct measurement of dissolved organic nitrogen (DON) was not achievable, DON was derived by subtracting $\mathrm{NO}_{3}-\mathrm{N}$ and $\mathrm{NH}_{4}-\mathrm{N}$ (inorganic form) from TDN. Nutrient exports were calculated by multiplying average nutrient concentrations for each plot and runoff event by the total runoff volume and then dividing by the plot area.

Data for all parameters were analyzed using repeated measures analyses of variance. Sample date was used as the repeated measures, using the "proc mixed" model in SAS 9.4 (SAS Institute, Cary, NC) to determine statistical significance of results. Data were analyzed and presented by years. Means were separated following Tukey's honestly significant difference test at $P \leq 0.05$.

\section{Results}

Water droplet penetration time. At the initiation of the study, water droplet penetration time was less than $1 \mathrm{~s}$ for all treatments at the $2.5 \mathrm{~cm}$ depth and ranged from 4.9 to $6.5 \mathrm{~s}$ at the $5 \mathrm{~cm}$ depth. Based on the classification of water repellency developed by Bisdom et al. (1993), soils at the $2.5 \mathrm{~cm}$ depth would be considered wettable, while the $5 \mathrm{~cm}$ depth would be considered slightly water repellent.

Environmental conditions. Weekly average air temperature ranged from 20 to $30^{\circ} \mathrm{C}$ in 2015. For 2016, air temperatures averaged between 20 to $30{ }^{\circ} \mathrm{C}$ for the initial 12 weeks, but they reduced after week 13 through the remainder of the study (Fig. 1). Weekly average $\mathrm{ET}_{\mathrm{o}}$ were greater for the 2015 study period than the 2016 study period for most 


\begin{tabular}{|c|c|c|c|c|c|c|c|c|}
\hline & \multicolumn{8}{|c|}{ ANOVA } \\
\hline & \multicolumn{2}{|c|}{ Soil moisture } & \multicolumn{2}{|c|}{ Runoff vol } & \multicolumn{2}{|c|}{$\%$ green cover } & \multicolumn{2}{|c|}{ Turfgrass quality } \\
\hline Date (D) & $* * *$ & $* * *$ & $* * *$ & $* * *$ & $* * *$ & $* * *$ & $* * *$ & $* * *$ \\
\hline Fertilizer $(\mathrm{F})$ & NS & * & NS & NS & $* * *$ & ** & * & $* * *$ \\
\hline $\mathrm{D} \times \mathrm{WA}$ & NS & NS & NS & NS & NS & NS & NS & NS \\
\hline $\mathrm{D} \times \mathrm{F}$ & NS & NS & NS & NS & NS & NS & NS & NS \\
\hline $\mathrm{WA} \times \mathrm{F}$ & $* * *$ & * & NS & NS & NS & NS & NS & NS \\
\hline
\end{tabular}

*Significant at $P=0.05 ; * *$ significant at $P=0.01 ; * * *$ significant at $P=0.001$; NS $=$ nonsignificant at $P=0.05$.

$\mathrm{Vol}=$ volume; $\mathrm{D}=$ measuring date; $\mathrm{WA}=$ wetting agent; $\mathrm{F}=$ fertilizer.

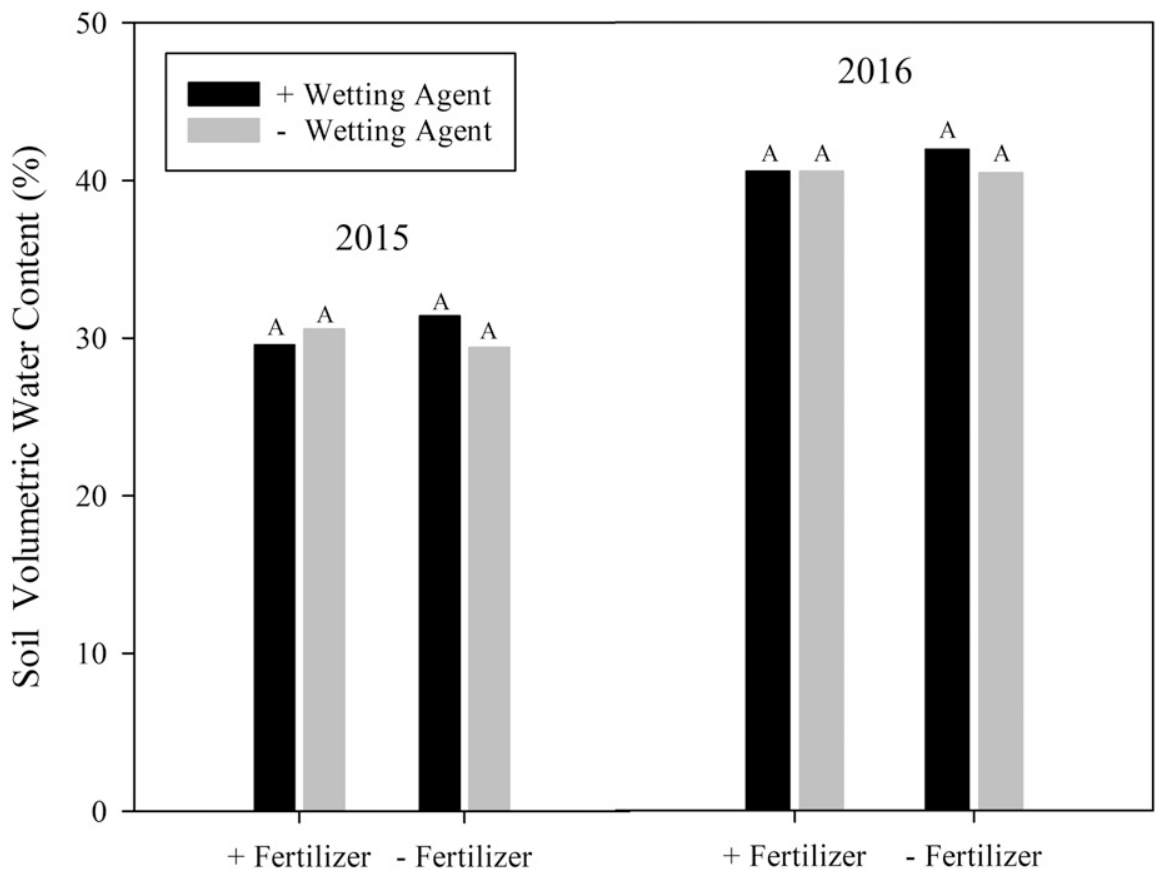

Fig. 3. Effect of wetting agent and fertilizer on soil volumetric content (\%) during the study period in 2015 16. Means were compared at each fertilizer level in each year with Tukey's honestly significant difference at $P=0.05$. Same letter means no significant difference.

weeks, with a range of 2.0 to $7.5 \mathrm{~mm}$ and 1.3 to $6.6 \mathrm{~mm}$ for 2015 and 2016 , respectively (Fig. 1).

Precipitation is presented as weekly cumulative precipitation rather than daily precipitation during the study period for both years, because several rainfall events lasted for several days and runoff was only measured after rainfall had completely stopped. Precipitation patterns varied each year (Fig. 2). Total precipitation for the 2015 study period was $379 \mathrm{~mm}$, which was less than the 35 -year historical average $(417 \mathrm{~mm})$ for the time period at the location. Precipitation events were erratic in 2015, with relatively little rainfall between weeks 5 and 20 before a rain event resulting in $190 \mathrm{~mm}$ of water during week 21 (Fig. 2). For 2016, rainfall was $7 \%$ greater than normal for the 21 -week study period (452 vs. $421 \mathrm{~mm}$ ). Several heavy rain events leading to weekly cumulative precipitation greater than $50 \mathrm{~mm}$ occurred during 2016 (Fig. 2). Reduced $\mathrm{ET}_{\mathrm{o}}$ resulted from lower temperatures and greater precipitation in 2016, creating an overall wetter season compared with 2015 .
Treatment effects on soil moisture. The effects of wetting agent and fertilizer on soil moisture, turfgrass quality, percent green cover, and runoff volumes for both years are presented in Table 2. Analysis of variation indicated an interaction between wetting agent and fertilizer on soil moisture for both years. As such, wetting agents influenced volumetric water content differently within each fertilizer level; but under each fertilizer level, wetting agents resulted in similar volumetric water content as untreated plots during both years (Fig. 3). Overall soil volumetric water content for all treatments was also noticeably lower in 2015 than in 2016 ( $30 \%$ vs. $40 \%$ mean volumetric water content for 2015 and 2016 rating dates, respectively) (Fig. 3). Soil water content differences between years likely resulted from greater precipitation amounts and low $\mathrm{ET}_{\mathrm{o}}$ during the 2016 study period (Figs. 1 and 2).

Treatment effects on runoff volumes. No significant differences in runoff volumes were detected during the study due to wetting agent or fertilizer treatments (Table 2). Rather, runoff differences occurring from the st. augustinegrass plots were only affected by date, primarily due to differences in rainfall intensity and soil moisture content between runoff dates (Fig. 2, Table 2). Although 14 total precipitation events occurred during 2015 and 12 during 2016, only six of the precipitation events each year generated runoff (Figs. 2 and 4). In general, precipitation events greater than $13 \mathrm{~mm}$ were required to generate measurable runoff. The greater rainfall that occurred in 2016 compared with 2015 resulted in greater runoff volumes in 2016 than in 2015 (Figs. 2 and 4). The greatest runoff volume of $2016(\approx 3500 \mathrm{~L})$ was associated with runoff event 3 that was measured on week 5 , following 2 weeks of intensive rainfall (weeks 4 and 5); whereas the greatest runoff volume of $2015(\approx 2200$ L) was associated with runoff event 6 when a $190-\mathrm{mm}$ rain event occurred, detected on week 21 (Figs. 2 and 4).

Treatment effects on turfgrass quality and percent green cover. St. augustinegrass turfgrass quality was affected by wetting agent and fertilizer treatments during the study (Table 2). For turfgrass quality and percent green cover, no interaction of main effects was measured. Therefore, the influence of wetting agent and fertilizer levels are presented by main effects. However, although an effect of fertilizer was detected on turfgrass quality (Table 2), no differences were observed between fertilized and unfertilized plots in 2015. Fertilized plots resulted in greater turfgrass quality than unfertilized plots in 2016, with values of 8 and 7.5 for fertilized and unfertilized plots, respectively (Fig. 5). In comparison, wetting agent application as a main effect led to increased turfgrass quality for both years (Fig. 6). In 2015 , wetting agents resulted in a turfgrass quality of 7.1 , compared with nontreated plots, which averaged 6.8 in value. In 2016, the turfgrass quality rating value was 8 and 7.6 for wetting agent-treated and nontreated plots, respectively. Despite the deficit levels of supplemental irrigation $\left(0.3 \times \mathrm{ET}_{\mathrm{o}}\right)$, turfgrass quality for all treatments remained above the minimally acceptable level both years due to periodic rainfall events occurring during the study period.

Percent green cover was affected by fertilizer both years, and by wetting agent in 2016. Despite a statistical difference, fertilizer treatments had only a minimal effect on percent green cover, with $87 \%$ and $89 \%$ for 


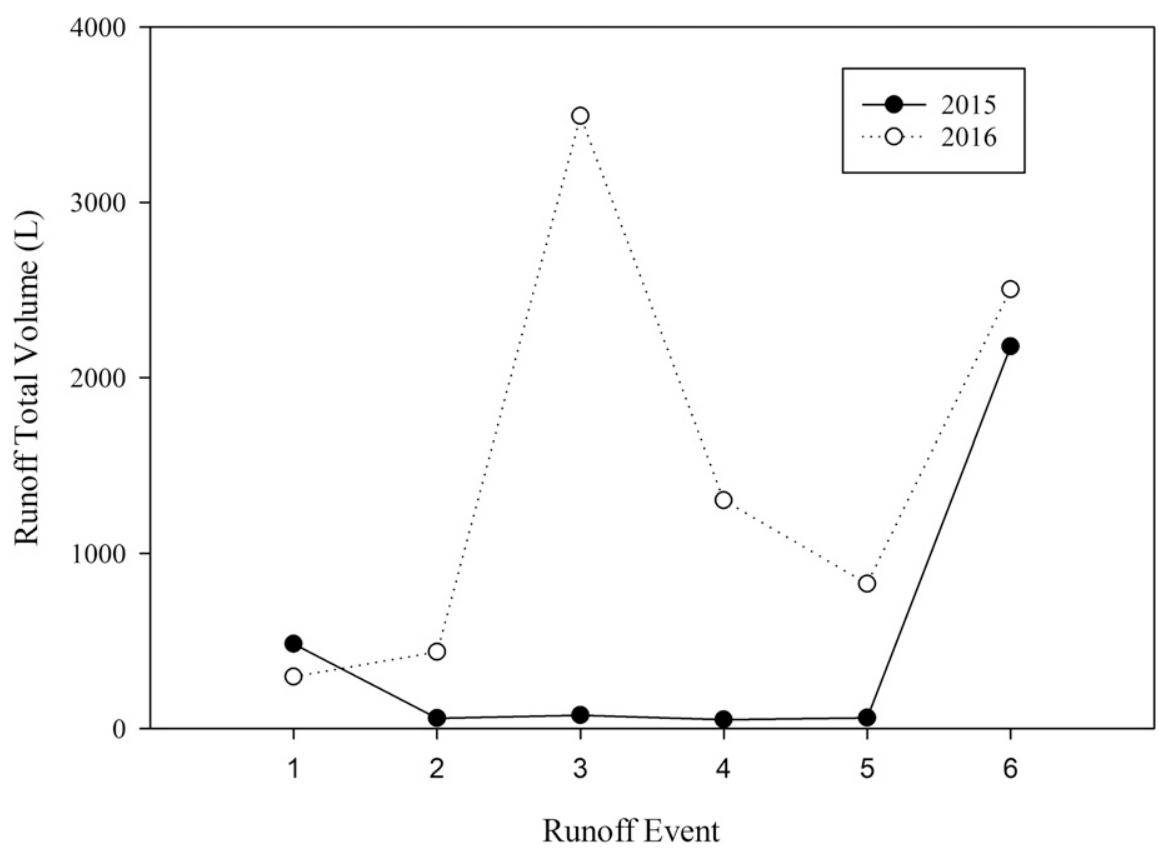

Fig. 4. Total runoff volumes occurring with measured rain events during both years. For reference, total precipitation occurring with each event is noted in the figure. Dates for each event are as follows: (2015) 1 = 17 June (week 2), 2 = 19 June (week 3), 3 = 12 Aug. (week 11), $4=23$ Sept. (week 14), $5=$ 20 (week 21), $6=26$ Oct. (week 21); (2016) 1 = 16 Aug. (week 4), $2=19$ Aug. (week 4), $3=23$ Aug. (week 5), 4 = 24 Sept. (week 10), 5 = 7 Nov. (week 16), $6=6$ Dec. (week 20).

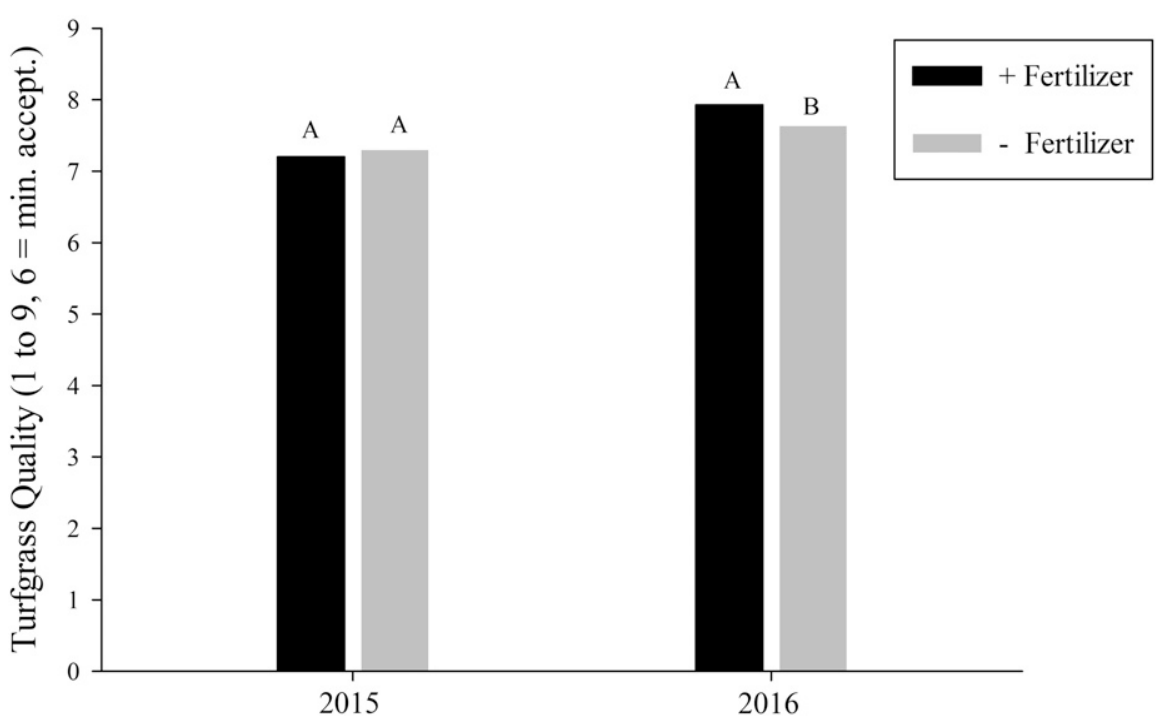

Fig. 5. Turf quality as affected by fertilizer during the study period in 2015 and 2016. Data are pooled across weeks. Means with the same letter in a year are not statistically different based on Tukey's honestly significant difference at $P=0.05$.

unfertilized and fertilized plots, respectively (data are not shown in figure). Percent green cover was increased by the application of the wetting agent, especially in the absence of fertilizer (Fig. 7). Wetting agent application resulted in a greater percent of green cover, with $91 \%$ and $85 \%$ green cover for wetting agent-treated and nontreated plots, respectively (Fig. 7).

Runoff nutrient exports. The main effects of wetting agent, fertilizer, and their interaction on nutrient exports in runoff are shown in fertilizer was applied before the runoff event, or runoff intensity was significantly high (Fig. 9A). Specifically, fertilized plots had greater TDN exports on both the initial $(80$ vs. $40 \mathrm{mg} \cdot \mathrm{m}^{-2}$ for fertilized and unfertilized, respectively) and final (700 vs. $200 \mathrm{mg} \cdot \mathrm{m}^{-2}$ for fertilized and unfertilized, respectively) runoff dates in 2015. No main effect of wetting agent or fertilizer were found on TDN in 2016. The interaction between date and fertilizer on TDN and DON found in 2015 was also not found in 2016.

Effects of wetting agent and fertilizer on DON and DOC were similar to that of TDN exports during both years of the study (Table 3), which is not surprising given that organic nitrogen was the largest fraction of TDN and it was also related to DOC. Dissolved organic nitrogen represented $70 \%$ to $90 \%$ of all $\mathrm{N}$ exports during runoff events in 2015, and greater DON export was associated with fertilized rather than unfertilized plots on two of six dates (Fig. 9B). A similar pattern was found for DOC in 2015, but a significant difference between fertilized and unfertilized plots was only found on 26 Oct. 2015 (Fig. 9C).

Total $\mathrm{PO}_{4}-\mathrm{P}$ exports were not influenced by wetting agent or fertilizer treatments (Table 3). In 2015, $\mathrm{PO}_{4}-\mathrm{P}$ exports for all plots averaged less than $60 \mathrm{mg} \cdot \mathrm{m}^{-2} \mathrm{P}$ per event for the first five runoff events, and $\mathrm{PO}_{4}$ $\mathrm{P}$ export from fertilized plots were greater than from unfertilized plots on the final (26 Oct. 2015) event (1029 vs. $494 \mathrm{mg} \cdot \mathrm{m}^{-2} \mathrm{P}$ for fertilized and unfertilized plots, respectively) (Fig. 9D).

\section{Discussion}

Wetting agents have been widely used in the turf industry for ameliorating hydrophobic soil conditions and improving water use efficiency. This study evaluated runoff, soil moisture, and turf canopy responses to wetting agent applications on a fine sandy loam soil with little to no detectable hydrophobicity at the onset of the study. No benefits from wetting agent were observed in terms of reduction in runoff. Previous studies have also shown limited effects of wetting agents on improving water retention and reducing runoff from nonhydrophobic soils (Lehrsch et al., 2011; Miller et al., 1975; Mitra et al., 2006; Miyamoto, 1985). For example, a controlled laboratory experiment found wetting agents did not affect runoff from three wettable soils for which water droplet penetration times were less than $5 \mathrm{~s}$ (Lehrsch et al., 2011). Another study evaluating the effect of wetting agent on runoff of irrigation water found that application of a widely used wetting agent (Dispatch; Aquatrols, Paulsboro, $\mathrm{NJ}$ ) reduced total irrigation runoff relative to controls; however, subsurface seepage was identified as contributing to these differences (Mitra et al., 2006). It has been suggested that wetting agents may influence soil moisture through affecting dynamics of water movement in the soil. Miller et al. (1975) evaluated wetting agent effects 
on water infiltration through wettable and water-repellent soils and noted that while infiltration rate was constant for wettable soils treated with a wetting agent, an initial decrease and subsequent sharp increase in infiltration rate was observed for wetting agent-treated water-repellent soils, reflecting

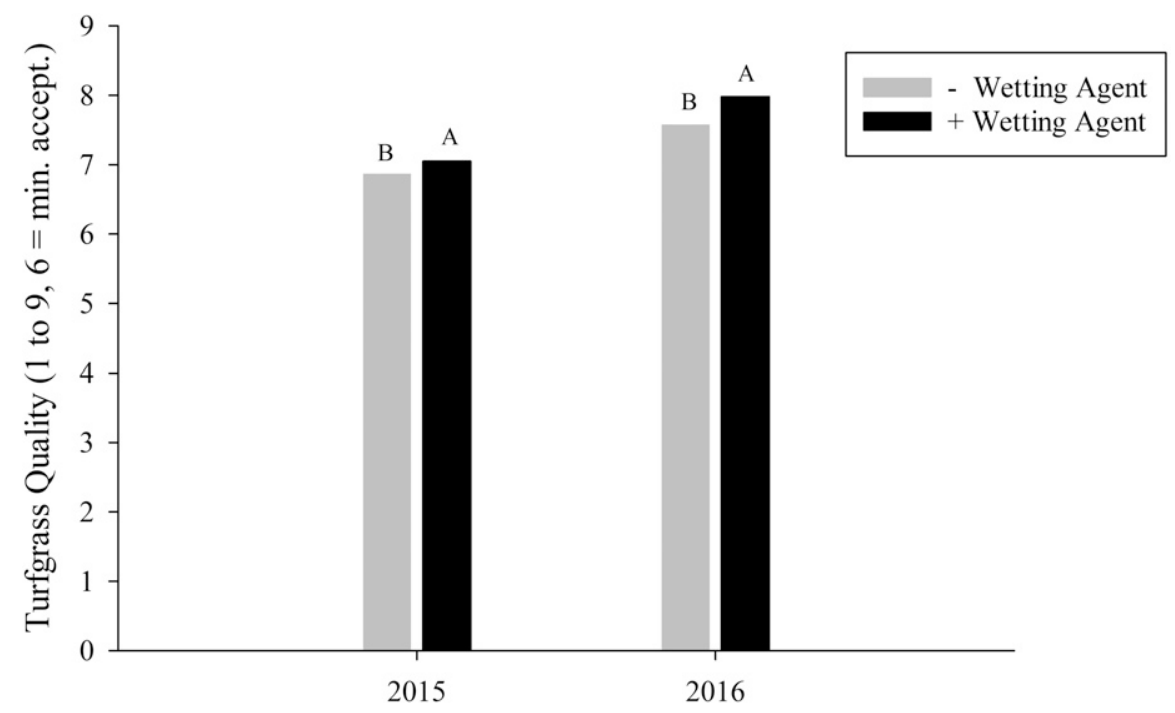

Fig. 6. Effect of wetting agent on turf quality in 2015 and 2016. Data are pooled across weeks. Means with the same letter in a year are not statistically different based on Tukey's honestly significant difference at $P=0.05$.

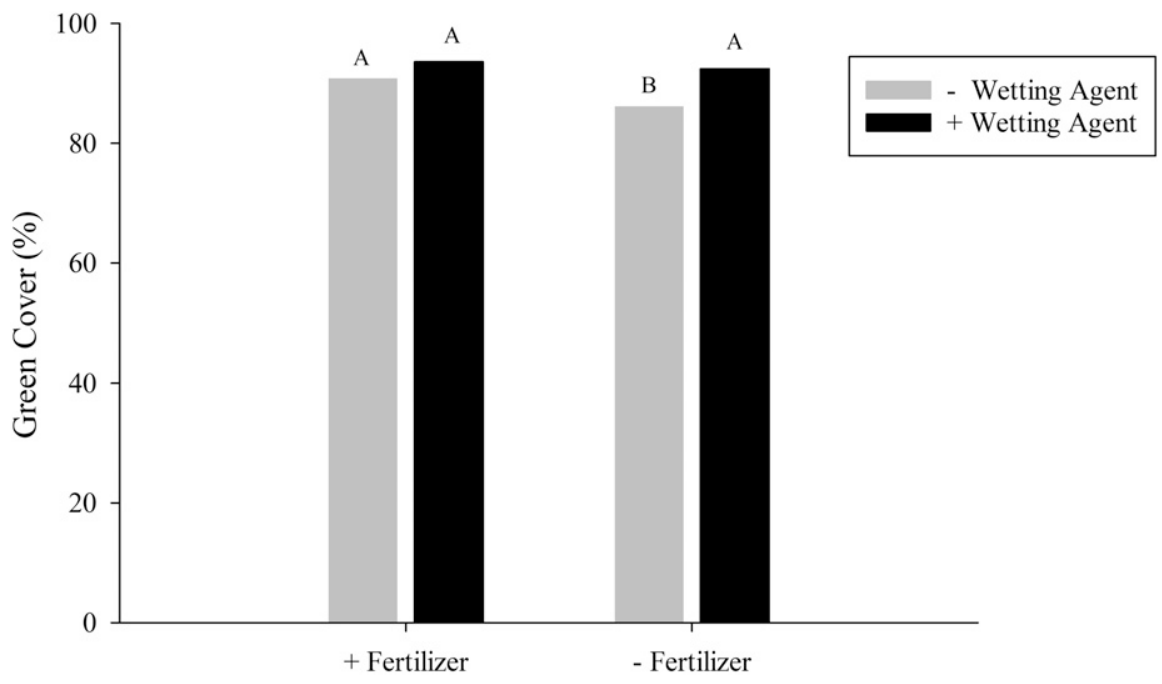

Fig. 7. Effect of wetting agent and fertilizer on plot percent green cover during 2016. Means with the same letter are not statistically different based on Tukey's honestly significant difference at $P=0.05$. although soil volumetric content and surface runoff volumes may not be affected by wetting agents, wetting agents may improve water holding capacity of the soil by reducing leaching or deep percolation of water below the root zone, thus increasing turfgrass quality as a result of greater water use efficiency by plants.

Several studies have confirmed the positive benefits of wetting agents on turfgrass quality; however, the majority of these studies have been on sand-based systems (Barton and Colmer, 2011; Kostka, 2000; Leinauer et al., 2007; Miyamoto, 1985; Soldat et al., 2010). Schiavon et al. (2014) reported turfgrass quality of Cynodon dactylon L. 'Princess $77^{\prime}$ and Paspalum vaginatum Swartz 'Sea Spray' was not improved by a wetting agent application and hypothesized that the negative effects of the saline irrigation water used may have offset beneficial effects of wetting agents. Although the irrigation water used in our study was sodic (SAR > 15), application of a wetting agent provided turfgrasses a greater opportunity to maintain a high quality over a longer period of time.

The observed increase in turf quality due to a wetting agent, even though practically speaking the difference is of little value, could also be related to effects on plant nutrient uptake. Chaichi et al. (2017) evaluated the effects of wetting agents on nutrient uptake efficiency of 'Bush Beefsteak' tomato plants, and they reported that wetting agents aided uptake of $\mathrm{N}$ and $\mathrm{K}$ in saline soils. Similarly, a study testing the growth of Argyranthemum coronopifolium (daisy) on wetting agent-treated peat found that plant $\mathrm{Ca}$ uptake was increased by the wetting agent (Cid-Ballarin et al., 1998). However, since effects of wetting agents on either turfgrass foliar or root uptake of nutrients were not directly measured in this study, these need to be confirmed through future studies.

In established turf, runoff losses of $\mathrm{N}$ can be relatively low compared with other pathways (Sebilo et al., 2013), which may explain why differences due to wetting agent were difficult to detect. Shuman (2002) measured $\mathrm{N}$ and $\mathrm{P}$ runoff losses following fertilizer applications to simulated 'Tifway' bermudagrass [Cynodon dactylon (L.) Pers. $\times C$. transvaalensis Burtt-Davy] golf course fairways and found that total nitrate- $\mathrm{N}$ loss via runoff $7 \mathrm{~d}$ after fertilization was 1.5 and $0.9 \%$ of applied for both 12 and $24 \mathrm{~kg} \cdot \mathrm{ha}^{-1} \mathrm{~N}$ application rates, respectively. Similar

Table 3. Repeated measurement analysis of variance (ANOVA) for chemical exports measured during runoff events in 2015 and 2016.

\begin{tabular}{|c|c|c|c|c|c|c|c|c|c|c|c|c|}
\hline \multirow{2}{*}{ Source } & \multicolumn{12}{|c|}{ ANOVA (export) } \\
\hline & \multicolumn{2}{|c|}{$\mathrm{NO}_{3}-\mathrm{N}$} & \multicolumn{2}{|c|}{$\mathrm{NH}_{4}-\mathrm{N}$} & \multicolumn{2}{|c|}{ TDN } & \multicolumn{2}{|c|}{ DON } & \multicolumn{2}{|c|}{ DOC } & \multicolumn{2}{|c|}{$\mathrm{PO}_{4}-\mathrm{P}$} \\
\hline$\overline{\text { Date (D) }}$ & $* * *$ & $* *$ & $* * *$ & $* * *$ & $* * *$ & $* * *$ & $* * *$ & $* * *$ & $* * *$ & $* * *$ & $* *$ & $* * *$ \\
\hline Fertilizer $(\mathrm{F})$ & NS & NS & * & NS & * & NS & * & NS & * & NS & NS & NS \\
\hline $\mathrm{D} \times \mathrm{WA}$ & NS & NS & NS & NS & NS & NS & NS & NS & NS & NS & NS & NS \\
\hline $\mathrm{D} \times \mathrm{F}$ & NS & NS & NS & NS & $* *$ & NS & $* *$ & NS & $* *$ & NS & * & NS \\
\hline $\mathrm{WA} \times \mathrm{F}$ & NS & NS & NS & NS & NS & NS & NS & NS & NS & NS & NS & NS \\
\hline
\end{tabular}

*Significant at $P=0.05 P$ level; **significant at $P=0.01$; ** significant at $P=0.001$; NS $=$ nonsignificant at $P=0.05$. 
results were reported by Cole et al. (1997), who applied $\mathrm{N}$ as either urea or sulfur-coated urea to bermudagrass at $49 \mathrm{~kg} \cdot \mathrm{ha}^{-1} \mathrm{~N}$ and reported runoff $\mathrm{N}$ losses of only $1.8 \%$ of

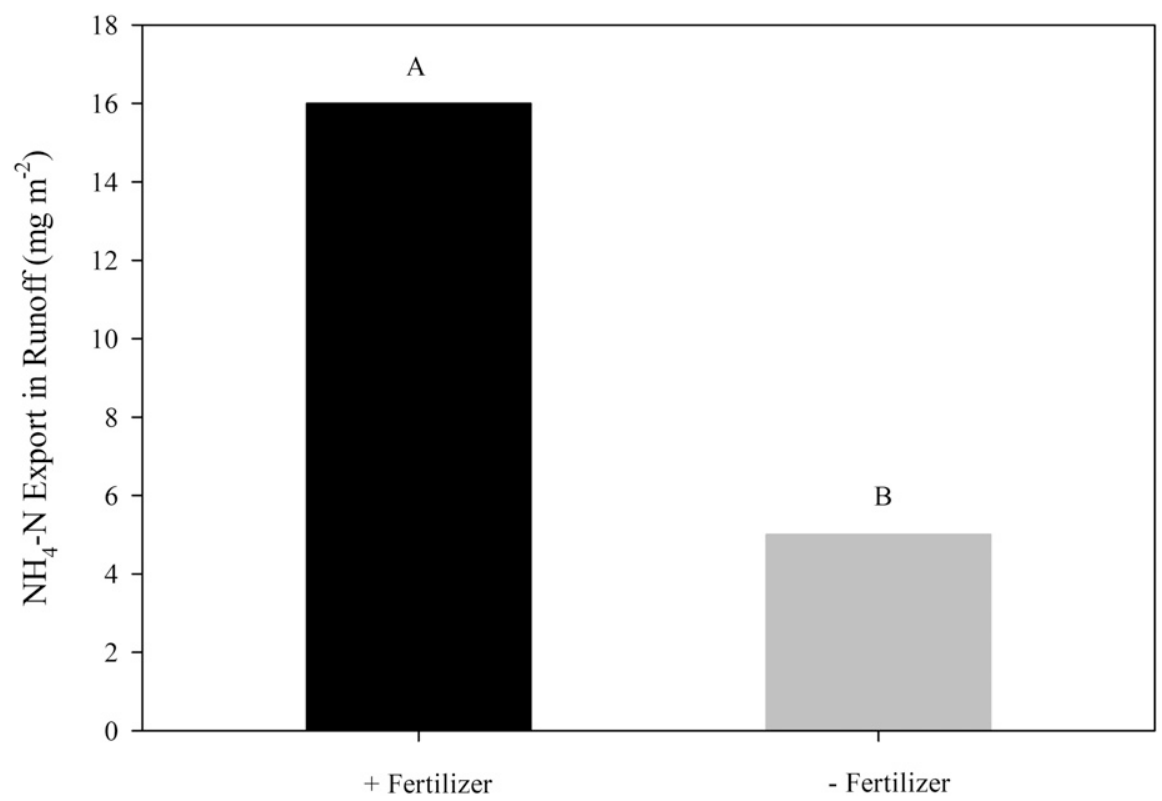

Fig. 8. Effect of fertilizer on NH4-N export in runoff during 2015. Data were pooled across all runoff events. Means with the same letter are not statistically different based on Tukey's honestly significant difference at $P=0.05$.
$\mathrm{NO}_{3}-\mathrm{N}$ and $2.1 \%$ of $\mathrm{NH}_{4}-\mathrm{N}$ from sulfurcoated urea and $2.4 \%$ of $\mathrm{NO}_{3}-\mathrm{N}$ and $6.4 \%$ of $\mathrm{NH}_{4}-\mathrm{N}$ from urea. In addition, a study conducted at the same study site as ours examined the effects of fertilizer and irrigation regimes on $\mathrm{NO}_{3}-\mathrm{N}$ export and reported that $\mathrm{NO}_{3}-\mathrm{N}$ exports in runoff from the system were predominantly driven by water inputs, especially during winter and early spring, when soil moisture was high and turf growth was minimal (Fontanier et al., 2017).

In this study, the effect of wetting agent on reducing nutrient and water losses through runoff was not significant, and fertilizer was a greater contributor to nutrient exports in runoff. In addition, the interaction between date and fertilizer on TDN and DON found in 2015 but not in 2016 is likely due to fertilizer being assimilated by turfgrass or moved into soil before the following runoff event (about 2 weeks after fertilization in 2016); and as a reference, several studies have shown that most uptake of $\mathrm{N}$ fertilizer by turfgrasses could be within days of fertilization during active growth periods (Bowman et al., 2006; Chang et al., 2019; Wherley et al., 2009). Although wetting agent treatment did not affect DOC exports as runoff, return of clippings to plots during mowing events and effects of high $\mathrm{Na}$ concentrations in irrigation likely contributed to the relatively high DOC exports observed (Steele and AitkenheadPeterson, 2013). Accordingly, we recommended that wetting agents should not be used as a common practice by turfgrass managers for the purpose of minimizing
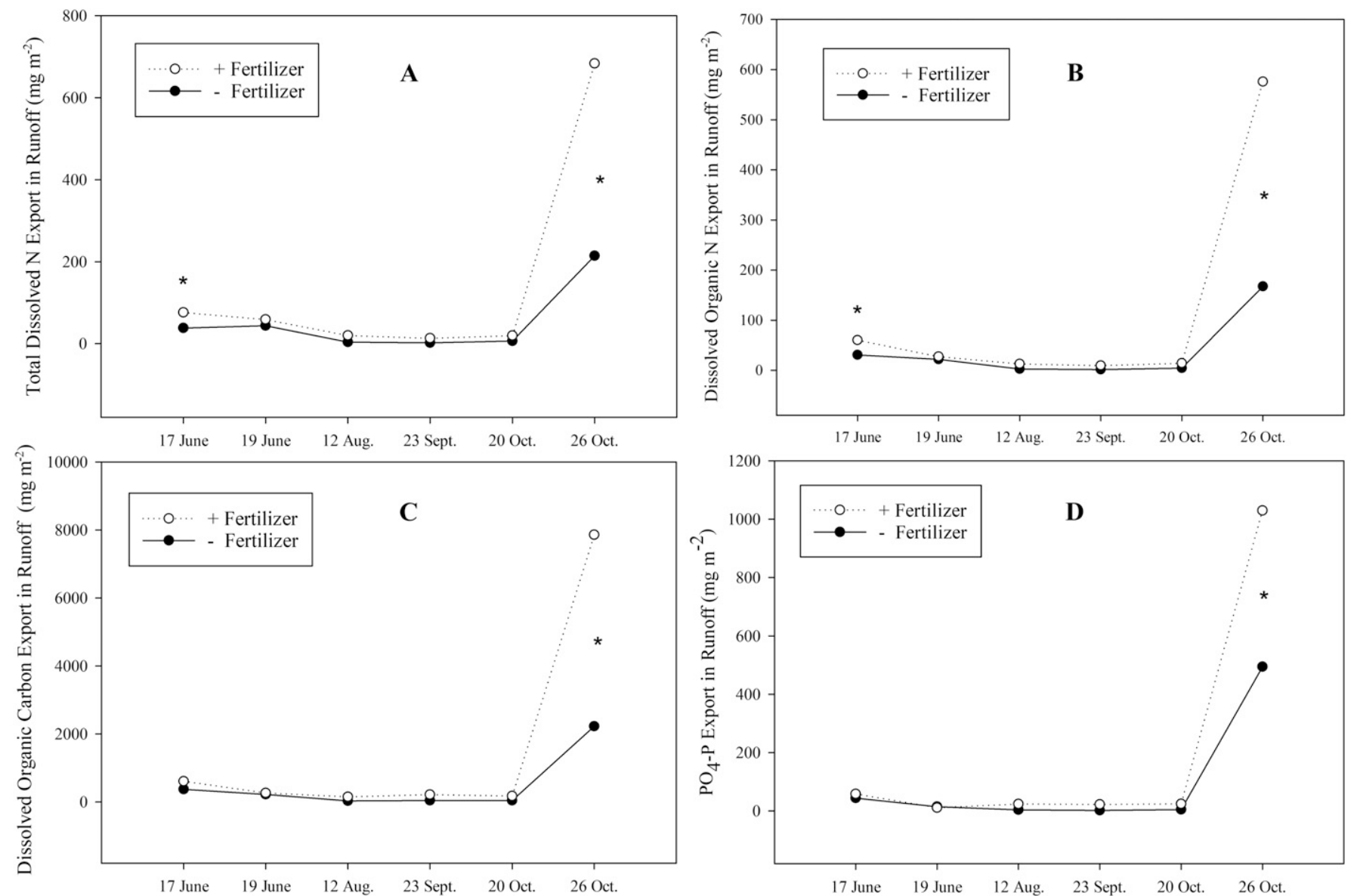

Fig. 9. Effect of fertilizer on total dissolved N, dissolved organic N, C, and $\mathrm{PO}_{4}-\mathrm{P}$ export in runoff during each runoff event in 2015 season. Data are pooled across surfactant treatment. * indicates a significant mean difference between fertilizer treatment based on Tukey's honestly significant difference at $P=0.05$. 
nutrient losses through runoff, especially for N. Timing of fertilization, however, should be given greater attention, as the potential for nutrient losses in runoff could be enhanced if fertilizer application is made just before heavy rainfall.

Although the wetting agent was found ineffective at ameliorating water and nutrient losses through runoff, we found increased turfgrass quality resulting from application of the wetting agent. One possible assumption is that a wetting agent aids retention of water and nutrients in the soil for a longer period of time, resulting in fewer losses. While nutrient leaching in our study was not measured, previous studies have shown that wetting agents offer potential to reduce $\mathrm{NO}_{3}-\mathrm{N}$ leaching (Arriaga et al., 2009; Cooley et al., 2009), making this a meaningful topic for turfgrass scientists for their future studies.

\section{Conclusions}

This 2-year field study evaluated potential for wetting agents to improve turf performance as well as to reduce runoff losses of water and nutrients from st. augustinegrass lawns. Based on the results of this 2-year field study, wetting agents provided mild improvements in turfgrass quality and percent green cover in plots and no negative effects on runoff and nutrient movement. However, their benefits did not extend to significant reductions in runoff water volumes or nutrient exports during precipitation events. Fertilizer application resulted in improved turfgrass quality only in the second season, likely due to nutrient losses in runoff in first year. Despite irrigating plots to $0.3 \times \mathrm{ET}_{\mathrm{o}}$, all plots maintained acceptable quality throughout the study, regardless of wetting agent treatment. This was likely due to the occurrence of timely rainfall events, which may have limited the potential benefits of wetting agent treatments. Therefore, a wetting agent application, regardless of year, is more an insurance application due to unknown drought. Future research should examine these treatments under greater levels of water stress to fully understand the extent of benefits they may offer for lawn situations. If limited benefits would still be observed at greater levels of water stress, additional research could address wetting agent effects on nutrient leaching and/or soil water dynamics.

\section{Literature Cited}

Aamlid, T.S., T. Espevig, and A. Kvalbein. 2009. The potential of a surfactant to restore turfgrass quality on a severely water-repellent golf green. Biologia 64:620-623.

Arriaga, F.J., B. Lowery, and K.A. Kelling. 2009. Surfactant impact on nitrogen utilization and leaching in potatoes. Amer. J. Potato Res. 86:383-390.

Barton, L. and T.D. Colmer. 2011. Ameliorating water repellency under turfgrass of contrasting soil organic matter content: Effect of wetting agent formulation and application frequency. Agr. Water Mgt. 99:1-7.

Beard, J.B. and R.L. Green. 1994. The role of turfgrasses in environmental protection and their benefits to humans. J. Environ. Qual. 23:452-460.

Bisdom, E.B.A., L.W. Dekkerand, and J.T. Schoute. 1993. Water repellency of sieve fractions from sandy soils and relationships with organic material and soil structure. Soil Structure/Soil Biota Interrelationships 56:105-118.

Bowman, D.C., G.R. Cramer, and D.A. Devitt. 2006. Effect of salinity and nitrogen status on nitrogen uptake by tall fescue turf. J. Plant Nutr. 29:1481-1490.

Burwell, R.E., D.R. Timmons, and R.F. Holt. 1975 Nutrient transport in surface runoff as influenced by soil cover and seasonal periods. Soil Sci. Soc. Amer. J. 39:523-528.

Cabrera, R.I., K.L. Wagner, B. Wherley, and L. Lee. 2013. Urban Landscape Water Use in Texas. TWRI EM-116. 15 Jan. 2020. $<$ https:// twri.tamu.edu/media/2526/em-116_urbanland scapewateruse.pdf>.

Carey, R.O., G.J. Hochmuth, C.J. Martinez, T.H Boyer, V.D. Nair, M.D. Dukes, G.S. Toor, A.L. Shober, J.L. Cisar, L.E. Trenholm, and J.B. Sartain. 2012. A review of turfgrass fertilizer management practices: Implications for urban water quality. HortTechnology 22:280-291.

Carrow, R.N., D.V. Waddington, and P.E. Rieke. 2001. Enhancing turfgrass nutrient-use efficiency, p. 33-41. In: Turfgrass soil fertility and chemical problems: Assessment and management. Ann Arbor Press, Chelsea, MI.

Chaichi, M.R., R. Keshavarz-Afshar, B. Lu, and M. Rostamza. 2017. Growth and nutrient uptake of tomato in response to application of saline water, biological fertilizer, and surfactant. J. Plant Nutr. 40:457-466.

Chang, B., B.G. Wherley, J.A. Aitkenhead-Peterson, and J.B. West. 2019. Irrigation salinity effects on Tifway Bermudagrass growth and nitrogen uptake. Crop Sci. 59:2820-2828.

Cid-Ballarin, C., R. Muñoz-Carpena, A. SocorroMonzón, and G. González-Tamargo. 1998. Wetting agent effects on peat properties related to nutrient solution losses and plant growth. Acta Hort. 458:161-170.

Cisar, J.L., K.E. Williams, H.E. Vivas, and J.J. Haydu. 2000. The occurrence and alleviation by surfactants of soil-water repellency on sandbased turfgrass systems. J. Hydrol. (Amst.) 231:352-358.

Cole, J.T., J.H. Baird, N.T. Basta, R.L. Huhnke, D.E. Storm, G.V. Johnson, M.E. Payton, M.D. Smolen, D.L. Martin, and J.C. Cole. 1997. Influence of buffers on pesticide and nutrient runoff from bermudagrass turf. J. Environ. Qual. 26:1589-1598.

Cooley, E.T., B. Lowery, K.A. Kelling, P.E. Speth, F.W. Madison, W.L. Bland, and A. Tapsieva. 2009. Surfactant use to improve soil water distribution and reduce nitrate leaching in potatoes. Soil Sci. 174:321-329.

DeBano, L.F., L.D. Mann, and D.A. Hamilton. 1970. Translocation of hydrophobic substances into soil by burning organic litter. Soil Sci. Soc. Amer. J. 34:130-133.

Doerr, S.H., R.A. Shakesby, and R. Walsh. 2000. Soil water repellency: Its causes, characteristics and hydro-geomorphological significance. Earth Sci. Rev. 51:33-65.

Doerr, S.H., A.J.D. Ferreira, R.P.D. Walsh, R.A. Shakesby, G. Leighton-Boyce, and C.O.A. Coelho. 2003. Soil water repellency as a potential parameter in rainfall-runoff modelling: Experimental evidence at point to catchment scales from Portugal. Hydrol. Processes 17:363-377.

Fontanier, C.H., J.A. Aitkenhead-Peterson, B.G. Wherley, R.H. White, J.C. Thomas, and P. Dwyer. 2017. Deficit irrigation and fertility effects on $\mathrm{NO}_{3}-\mathrm{N}$ exports from St. Augustinegrass. J. Environ. Qual. 46:793-801.

Göbel, P., C. Dierkes, and W.G. Coldewey. 2007. Storm water runoff concentration matrix for urban areas. J. Contam. Hydrol. 91:26-42.

Hochmuth, G., T. Nell, J.B. Unruh, L. Trenholm, and J. Sartain. 2012. Potential unintended consequences associated with urban fertilizer bans in Florida-A scientific review. HortTechnology 22:600-616.

Hoss, F., J. Fischbach, and E. Molina-Perez. 2016. Effectiveness of best management practices for stormwater treatment as a function of runoff volume. J. Water Resour. Plan. Mgt. 142:05016009, doi: 10.1061/(ASCE)WR.19435452.0000684 .

Karcher, D.E. and M.D. Richardson. 2003. Quantifying turfgrass color using digital image analysis. Crop Sci. 43:943-951.

Karcher, D.E. and M.D. Richardson. 2005. Batch analysis of digital images to evaluate turfgrass characteristics. Crop Sci. 45:1536-1539.

Karnok, K.J., K. Xia, and K.A. Tucker. 2004 Wetting agents: What are they, and how do they work. Golf Course Mgt. 72:84-86.

King, K.W., R.D. Harmel, H.A. Torbert, and J.C. Balogh. 2001. Impact of a turfgrass system on nutrient loadings to surface water. J. Amer. Water Resour. Assoc. 37:629-640.

King, K.W. and J.C. Balogh. 2001. Water quality impacts associated with converting farmland and forests to turfgrass. Trans. ASAE 44: 569, doi: 10.13031/2013.6117.

Kostka, S.J. and P.T. Bially. 2005. Synergistic surfactant interactions for enhancement of hydrophilicity in water repellent soils. Intl. Turfgrass Soc. Res. J. 10:108-114.

Kostka, S.J. 2000. Amelioration of water repellency in highly managed soils and the enhancement of turfgrass performance through the systematic application of surfactants. J. Hydrol. (Amst.) 231:359-368.

Laha, S., B. Tansel, and A. Ussawarujikulchai. 2009. Surfactant-soil interactions during surfactantamended remediation of contaminated soils by hydrophobic organic compounds: A review. J. Environ. Mgt. 90:95-100.

Lehrsch, G.A., R.E. Sojka, J.L. Reed, R.A. Henderson, and S.J. Kostka. 2011. Surfactant and irrigation effects on wettable soils: Runoff, erosion, and water retention responses. Hydrol. Processes 25:766-777.

Leinauer, B., P.E. Rieke, D. VanLeeuwen, R. Sallenave, J. Makk, and E. Johnson. 2001. Effects of soil surfactants on water retention in turfgrass rootzones. Intl. Turfgrass Soc. Res. J. 9:542-547.

Leinauer, B., D. Karcher, T. Barrick, Y. Ikemura, H. Hubble, and J. Makk. 2007. Water repellency varies with depth and season in sandy rootzones treated with ten wetting agents. Appl. Turfgrass Sci. 4, doi: 10.1094/ATS-2007-0221-01-RS

Lowery, B., F.J. Arriaga, and K.A. Kelling. 2002. August. Use of surfactant to decrease nitrate leaching and improve nitrogen use efficiency in potato production. In 17th World Congress of Soil Science, Bangkok, Thailand, Symposium Vol. 54:1-6.

McDowell, R.W. and A.N. Sharpley. 2001. Approximating phosphorus release from soils to surface runoff and subsurface drainage. J. Environ. Qual. 30:508-520.

Miller, W.W., N. Valoras, and J. Letey. 1975. Movement of two nonionic surfactants in wettable and water-repellent soils. Soil Sci. Soc. Amer. J. 39:11-16.

Mitra, S., E. Vis, R. Kumar, R. Plumb, and M. Fam. 2006. Wetting agent and cultural practices increase infiltration and reduce runoff losses 
of irrigation water. Biologia 61:S353-S357, doi: 10.2478/s11756-006-0188-4

Miyamoto, S. 1985. Effects of wetting agents on water infiltration into poorly wettable sand, dry sod and wettable soils. Irr. Sci. 6:271-279.

Morris, K.N. and R.C. Shearman. 2007. NTEP turfgrass evaluation guidelines. National Turfgrass Evaluation Program, Beltsville, MD. 12 Aug. 2019. $<$ http://www.ntep.org/pdf/rat-ings.pdf $>$.

National Cooperative Soil Survey. National Cooperative Soil Characterization Database. 2 Dec. 2019. <http://ncsslabdatamart.sc.egov.usda.gov/>

Novotny, V. and H. Olem. 1994. Water quality: Prevention, identification and management of diffuse pollution. Van Nostrand-Reinhold Publishers, New York.

Ozan, L.A. and K.A. Alsharif. 2013. The effectiveness of water irrigation policies for residential turfgrass. Land Use Policy 31:378-384.

Pelishek, R.E., J. Osbornand, and J. Letey. 1962. The effect of wetting agents on infiltration. Soil Sci. Soc. Amer. J. 26:595-598.

Racke, K.D. 2000. Pesticides for turfgrass pest management: Uses and environmental issues, p. 45-64. In: Fate and management of turfgrass chemicals, ACS Symposium Series, Vol. 743, American Chemical Society, Washington, D.C. doi: 10.1021/bk-2000-0743.ch003.

Richardson, M.D., D.E. Karcher, and L.C. Purcell. 2001. Quantifying turfgrass cover using digital image analysis. Crop Sci. 41:1884-1888.
Schiavon, M., B. Leinauer, M. Serena, B. Maier, and R. Sallenave. 2014. Plant growth regulator and soil surfactants' effects on saline and deficit irrigated warm-season grasses: I. Turf quality and soil moisture. Crop Sci. 54:2815-2826.

Sebilo, M., B. Mayer, B. Nicolardot, G. Pinay, and A. Mariotti. 2013. Long-term fate of nitrate fertilizer in agricultural soils. Proc. Natl. Acad. Sci. USA 110:18185-18189.

Shuman, L.M. 2002. Phosphorus and nitrate nitrogen in runoff following fertilizer application to turfgrass. J. Environ. Qual. 31:1710-1715.

Soldat, D.J., B. Lowery, and W.R. Kussow. 2010. Surfactants increase uniformity of soil water content and reduce water repellency on sandbased golf putting greens. Soil Sci. 175:111117.

Steele, M.K. and J.A. Aitkenhead-Peterson. 2013. Salt impacts on organic carbon and nitrogen leaching from senesced vegetation. Biogeochemistry 112:245-259.

Taylor, G.D., T.D. Fletcher, T.H. Wong, P.F. Breen, and H.P. Duncan. 2005. Nitrogen composition in urban runoff-implications for stormwater management. Water Res. 39:19821989.

Throssell, C. 2005. GCSAA-USGA wetting agent evaluation. Golf Course Mgt. 73:52-91.

Wherley, B., M.D. Dukes, S. Cathey, G. Miller, and T. Sinclair. 2015. Consumptive water use and crop coefficients for warm-season turfgrass species in the Southeastern United States. Agr. Water Mgt. 156:10-18.

Wherley, B.G., R.H. White, K.J. McInnes, C.H. Fontanier, J.C. Thomas, J.A. AitkenheadPeterson, and S.T. Kelly. 2014. Design and construction of an urban runoff research facility. J. Vis. Expt. (90):e51540, doi: 10.3791/ 51540.

Wherley, B.G., W. Shi, D.C. Bowman, and T.W. Rufty. 2009. Fate of ${ }^{15} \mathrm{~N}-\mathrm{Nitrate}$ applied to a bermudagrass system: Assimilation profiles in different seasons. Crop Sci. 49:2291-2301.

Wherley, B.G., J.A. Aitkenhead-Peterson, N.C. Stanley, J.C. Thomas, C.H. Fontanier, R.H. White, and P. Dwyer. 2017. Nitrogen runoff losses during warm-season turfgrass sod establishment. J. Environ. Qual. 44:1137-1147.

White, R., R. Havlak, J. Nations, T. Pannkuk, J. Thomas, D. Chalmers, and D. Dewey. 2004. How much water is "enough"? Using PET to develop water budgets for residential landscapes. Texas Water Resources Institute TR271:1-8. <http://hdl.handle.net/1969.1/6100>.

Zisman, W.A. 1964. Relation of the equilibrium contact angle to liquid and solid constitution. Adv. Chem. Ser. 43:1-51.

Zontek, S.J. and S.J. Kostka. 2012. Understanding the different wetting agent chemistries. USGA Green Sec. Rec 50:1-6. 